\title{
Advertisement and the extrinsic cues toward buying attitude: Case of Wardah halal cosmetics
}

\author{
Dara Anggun Puspita Dewi ${ }^{1}$, Guruh Ghifar Zalzalah ${ }^{2 *}$ \\ ${ }^{1}$ Faculty of Economics, Universitas Islam Indonesia, Yogyakarta, Indonesia \\ ${ }^{2}$ Asean Business Institute, Universitas Islam Indonesia, Yogyakarta Indonesia \\ *Corresponding author: guruhghifar@gmail.com
}

\author{
Article History \\ Received, 4 February 2019 \\ Revised 1, 24 February 2019 \\ Revised 2, 21 March 2019 \\ Accepted, 14 May 2019
}

\begin{abstract}
Purpose: The aim of this research was to determine the influence of effective advertisement (emotional response and environmental response), extrinsic cues (brand image, packaging, and price) toward the consumer buying attitude, and to analyze the influence of extrinsic cues on consumer buying attitude of Wardah through income as the moderating variable.
\end{abstract}

Methodology: The sample was taken by female university students who used the product of Wardah. The sampling technique used was a non-probability sample that is convenience sampling or accidental sampling. The analytical tool used multiple linear regression analysis with SPSS version 20.

Findings: The results of multiple regression analysis showed a positive and significant influence on the effective advertisement (emotional response and environmental response), and extrinsic cues (brand image, packaging, and price) toward the consumer buying attitude, and income was positively moderated the extrinsic cues toward the consumer buying attitude.

Originality/Contributions: This is the first study to find out, the researcher focused on female university students in Yogyakarta who were using Wardah cosmetic. There were five parts of questions based on the effectiveness of advertising variables, brand image variables, packaging variables, pricing variables, income variables and buying attitude variables

Keywords: Profitability, leverage, firm size, dividend policy, growth opportunity, managerial ownership, firm value, Indonesian stock exchange.
Cite this:

Dewi, D.A.P \& Zalzalah, G.G. (2019). The influence effective advertisement and the extrinsic cues of Wardah toward consumer buying attitude of female university students in Yogyakarta, Asian Journal of Islamic Management, 1(1), x-xx. DOI: 10.1108/AJIM.vol1.iss1.art2

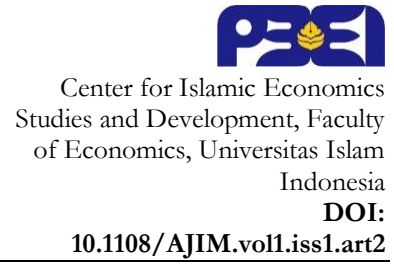

\section{Introduction}

Cosmetics are the part of women essential things. In Indonesia, the cosmetic industry grows fast and helps to develop the country to increase the economic growth of Indonesia. Furthermore, many of brands and products have their own image and position. The increasing of cosmetic about 15\% since 2012 has a very strict and strong competition in Indonesia (Global Business Guide Indonesia, 2014). Wardah Cosmetic is the one of local brand that has a brand image as the halal cosmetic in Indonesia. It produces a lot of products from make-up, cleanser, fragrance, face and body treatment, and also offering the affordable price with good quality and elegant 
packaging. Wardah has been succeeding in the market. It shows that it became the top brand of Indonesia in 2014 and became the pioneer of halal brand (Supriadi, 2014).

Wardah come in order to fulfill the demand of women in Indonesia who are seeking the halal product. This local brand has a halal certificate from LPOM MUI, which is becoming the image of the brand itself. Moreover, Wardah slogan is, "Pure and save, beauty expert and inspiring beauty". Therefore, in creating the brand awareness, Wardah stressed on the inner beauty. Beside that, in advertising Wardah, the company chooses endorser who matches with their brand image. Yogyakarta has many universities which means, the number of students each year is increasing enormously. The students mostly comes from other city. However, because they got monthly income from their parents (pocket money), it becomes one of the factors for decision making to purchase the cosmetics.

Thus, the researcher would like to know the effectiveness of wardah in terms of advertisement, and its extrinsic cues toward buying attitude of female university students in Yogyakarta with their income (pocket money) as the moderating variables.

\section{Literature Review and Hypothesis Development}

\section{Consumer Buying Attitude}

Consumer buying attitude is a part of activities of buying process that involves belief, trust, and emotional feeling and behavior intentions to purchase the product or brand repeatedly (Poranki \& Perwej, 2014). According to Hawkins et al.,(2004) cited in Carvalho (2013), those elements are explained as cognitive, affection, and behavior. Firstly, cognitive, component which is considered as the consumers' belief of the product as they finished to evaluate, for example, consumer trusts Wardah cosmetic as halal product and has a low price as an exclusive cosmetic. Secondly, affective component which is considered as the consumer reaction toward the product, for example the consumers are happy to have one of wardah products because it is fulfilling their need. Thirdly, a behavior component which is the action and the manner toward the object or the brand, for example the consumer purchases the product of the Wardah as their action to fulfill their need. (Abbasi, 2011; Brosekh. et al, 2011; Karbasivar \&Yarahmadi, 2011).

\section{Effective of Advertisement}

Advertisement is one of the promotional strategies. It creates brand image awareness of the brand in consumer's perspective in order to have an opportunity for persuading the consumer buying decision process (Kotler, 2001). However, choosing the advertisement is necessary to make a high influence on consumer which can be the greatest factor of buying decision making process (Malik et al., 2013). Kumar, 2013; Kumar, \& Kejriwal, 2014)

The marketers need to consider about the response of consumers toward the advertisement. There are three ways to know the responses from consumers. They are through the audience, cognitive, affective and behavioral response (Kotler, 2001). Previous research (Abideen, 2012), the effectiveness of advertisements can be seen by two types of responses from the consumer. When the advertisement shows the effectiveness, emotional and environmental responses, it is showing its role to influence the consumer to purchase the product. Therefore, from this response, advertisement can change their perspective, the attitude of the consumer, and also can show the experience of consumer toward the product. (Lin,. \& Tsai, 2006; Rehman, 2014).

\section{Emotional Response}

The emotional response happens when the advertising influences the personal emotion of consumer to buy the product (Abideen, 2012). Emotional response is when the advertisement can influence the attitude of the consumer. Thus, the attitude can be the perception and idea. 
According to Niazi et al. (2012) the consumer will be influenced by the advertisement through the pleasure, arousal, dominance, and brand recall. According to him, pleasure is an emotional feeling when people feel happy, enjoy, and satisfy; arousal is the emotional feeling varies which for every person, such as bored, sleepy, excited, and active; dominance is an emotional feeling which is more individual and is dominated by the other feeling, and it controls freely in certain situation.

The goal of advertising is to create and form the positive attitude and the advertising should have a positive emotional response in order to persuade the buyers to purchase the product (Goldsmith \& lofferty, 2002 as cited in Abideen, 2012).

From the above explanations, it can be concluded that people might get emotionally influenced by the advertisement when they trust and like the wardah advertisement and impulse them to buy. Wardah cosmetic has many advertisements which can increase and persuade the consumer to intentionally buy the product as they believed the brand as shown in advertisements. In this case, the hypothesis was as follows:

$\mathrm{H}_{1}$ : There was a significant relationship between emotional response and consumer buying attitude.

\section{Environmental Response}

The environmental response is when the advertising can create the experience of the consumer through the opinion and comment about the product (Abideen, 2012). The cognitive will largely influence the consumer than attitude because it contains lots of opinions from another consumer who had experienced about the product (Greenley \& Foxall, 1997 as cited in Abideen, 2012)

There are situational factors such as store environment (atmosphere, design, and employee assistance), the time pressure and also perceived crowding (Kebir, 2011). According to Kappas (2012) as cited in Arshad et al. (2014), environment can stimulate consumer by music, the design of the store, light, layout and employs of the stores. (Bashar, 2013).

From the above explanations, it can be concluded that Wardah stores can be affected by the environmental response when the buyers asks and tries the tester and at the same time the shopkeeper provided them information toward the brands. The researcher had found that the hypothesis of the relationship of advertisement which were an environmental and emotional response appear when people like the advertisement of Wardah and come to the Wardah stores. In this case, the hypothesis was as follows:

$\mathrm{H}_{2}$ : There was a significant relationship between environmental responses and ing attitude.

\section{Extrinsic Cues}

When women are looking for the cosmetics, as consumers, they would evaluate the product through the brand got influenced by the attributes of the information of the brand and turn to purchase the product. This is called as the cues (Pagis \& Chowdhury, 2006).

There are two characteristic of cues, intrinsic and extrinsic cues (Olson \& Jacoby, 1992 as cited in Acebro \& Dopico, 2000). According to Pagis \& Chowdhury (2006), the intrinsic cues are widely used to determine the physical characteristics which can influence the consumer perception about the product, while the extrinsic cues are the external characteristics of the product such as brand image, price, and packaging as the factors that can influence the consumer perception about the brand. (Saha, et al, 2010).

\section{Brand Image}

Brand is an image that people can easy to remember, recall, and give the positive perception of the product (Aaker, 1997 as cited in Fianto, 2014). Brand image is the perception of the public, according to the product using their rational and sometimes more emotional (feeling and attitude) 
toward the product and it gives the long term benefits for the company (Malhotra, 2010; Cannon, Perreault, \& McCarthy, 2009; Assael, 2004 as cited in Fianto 2014).

Brand image occurred and created because the marketers would like to position the brand in consumer perception (Malik et al, 2013). Brand image can help the consumers to identify and recognize their needs in order to satisfy their needs, and it can be also distinguished from the other competitor (Hsieh, Pan, \& Setiono, 2004 as cited in Anwar, 2011; Ayanwale, 2005; Yarahmadi, 2011).

When a positive brand image is created, the brand could form the brand association in order to make strong trust and retention of consumers who are satisfied with the brand as they also enable to create positive attitudes (Keller, 1993 as cited in Fianto, 2014). Brand image also represents the company on how the business or organization is able to describe itself by a symbol and slogan (Winarso, 2012 as cited in Fianto, 2014). The positive impression will arise when the brand has good reputation, trust worthy, and distinguish advantage (Kotler and Keller, 2012; Keller, 1993; Aaker, 1997 as cited in Fianto, 2014). In this case, the hypothesis was as follow: $\mathrm{H}_{3 a}$ : There was a significant relationship between brand image and consumer buying attitude.

\section{Packaging}

Packaging become an important strategy of product preference which can be the factors of buying decision and become the essential parts when the selling process is happening (Silayoi \& Speece, 2004 as cited in Dhurup, Afini, \& Dumasi, 2014). Packaging activities are concerned and related to the activities of design, production, and filling, also how to keep the product in good quality and protect the product whenever it is put in the store or transported and identified in the store (Kent \& Omar, 2003 as cited in Dhurup, Afini, \& Dumasi, 2014).

Packaging is also one of the communication tools between the companies and the consumers that many guarantee for the quality of the product (Ahmed, Parmar, \& Amin, 2014; Silayoi \& Speece, 2007 as cited in Dhurup, Afini, \& Dumasi, 2014). The purpose of packaging is to guarantee the quality of the product that the consumer minor experience, as logistic, communicate with consumers and maintain the sustainability of the product (Azzi et al. as cited in Hess et al., 2014.). Consumer experiences with the packaging will evaluate the product and have the perception of the brand (Hess et al., 2014; Abideen, Z. u. 2011).

Wardah cosmetic has its own standard of packaging, which is unique and different with other brand (Ciputra Entrepreneur, 2015). The packaging has a design with Tosca color and blue as the dominant color. The wardah concept shows the public that their packaging is simple but convenient and shows the image as nature and halal products. Usually wardah shows the halal label on the back side of the packaging.. In this case, the hypothesis was as follow:

$\mathrm{H}_{3 \mathrm{~b}}$ : There was a significant relationship between packaging and consumer buying attitude.

\section{Price}

Pricing is the crucial element in marketing. Price is a set of the monetary value of the product which are sold and offered for sale to consumers (Chatterjee, 2008 as cited in Dhurup, Afini, \& Dumasi, 2014). Price has its role in marketing as an important strategy which is directly related to the company's goals and its variable with marketing elements (Yesawich, 2004 as cited in Dhurup, Afini, \& Dumasi, 2014).

Price should be based on market demand because the price is a sensitive element which is concerned about the target of the brand itself (Kotler, 2001). Kotler (2001) also said that price is very sensitive when: 1) the product is distinctive; 2) buyers are less aware of subtleties; 3) buyers cannot easily compare the quality of substitute; 4) the expenditure is a lower part of buyer's total income; 5) the expenditure is small compared to the total costs of the end product; 6) part of the cost is borne by another party; 7) the product is used in related with asset previously bought; 8) the product is assumed to have more quality, prestige, or exclusiveness and; 9) buyers cannot 
store the product. It defines the kinds of product, builds the incentives to consumers, and gives signals to company competitors (Atchariyachanvanich \& itoshi, 2007 as cited in Dhurup, Afini, \& Dumasi, 2014). In this case, the hypothesis was as follow:

$\mathrm{H}_{3 \mathrm{c}}$ : There was a significant relationship between pricing and consumer buying attitude

\section{Income}

According to Nguyen \& Gizaw (2014), income can influence the attitude and style of consumers. Some researcher found that income has a positive relationship with buying attitude, but some others do not have a significant relationship between income and buying attitude (Waheed, Mahasan, \& Sandhu, 2014). Therefore, income has become the superior determinant of the consumer purchasing power (Dorota, 2013 as cited in Nguyen \& Gizaw, 2014).

In this research, the income of female university students is from their parents' salary. On the other hand, the pocket money is one of the income of the female university students that are able to support their living cost Yogyakarta. Therefore, this research used pocket money as the income of female university students. Women spend more to buy cosmetic because they are more cognitive than men (Shukre \& Mishra, 2012). Pocket money, income of female university students coould be moderating the extrinsic cues which were brand image, packaging, and price of the brand. In this case, the hypothesis were as follow:

$\mathrm{H}_{4 \mathrm{a}}$ : There is a significant relationship between the extrinsic cues and consumer buying attitude.

$\mathrm{H}_{4 \mathrm{~b}}$ : Income (pocket money) significantly moderates the influence of the extrinsic cues toward consumer buying attitude.

\section{Theoretical Framework}

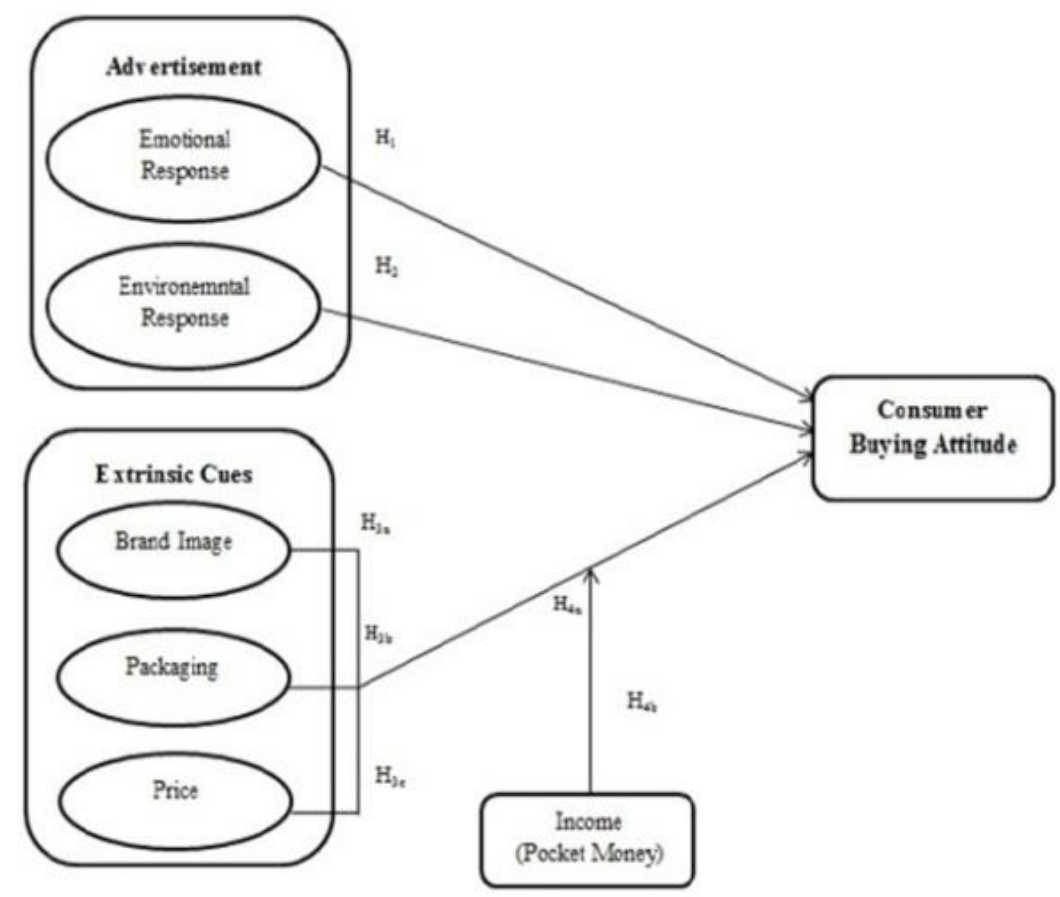

Figure 1. Theoretical Framework

\section{Research Method}

\section{Population and Sample}

This research used the quantitative research. The data collection method is primary data. The primary data was collected by conducting surveys through the consumers. Population is a group of individual in a community and gathers in certain locations (Ghozali, 2005). In this research, 
the researcher focused on female university students in Yogyakarta who were using Wardah cosmetic.

The researcher selected 200 samples which represented the population of female university students in Yogyakarta, but only 100 samples that had been shown as the representative of the population (Hadi, 2002 as cited in Habib, 2014). The method of sample was using non probability convenience sampling technique or Accidental Sampling. This method helps us to get the subject easiest and the sample was found in the location of the population (Battaglia, 2011). The questionnaires were given accidentally to the female university students in Yogyakarta who were using Wardah Cosmetic.

\section{Data Collection Method}

This research used primary data. The source data were directly taken from the respondents involved in this research. This research used a questionnaire to gather the data from the consumers, which was distributed to 220 respondents in Yogyakarta. From 220 questionnaires, the researcher received 200 questionnaires in the field. The type of questionnaire was closed questionnaire. There were five parts of questions based on the effectiveness of advertising variables, brand image variables, packaging variables, pricing variables, income variables and buying attitude variables

Table 1. The Operational of Research Variables

\begin{tabular}{|c|c|c|c|}
\hline Variable & Definition & Indicator & Measurement \\
\hline $\begin{array}{l}\text { Effective } \\
\text { advertisement } \\
\text { (Emotional } \\
\text { Response) } \\
\mathrm{X}_{1}\end{array}$ & $\begin{array}{l}\text { The emotional response } \\
\text { happens when the } \\
\text { advertising influences the } \\
\text { personal emotion of } \\
\text { consumer to buy the } \\
\text { product (Abideen, 2012) }\end{array}$ & $\begin{array}{l}\text { - Good advertisement of } \\
\text { Wardah. } \\
\text { The information of the } \\
\text { advertisement } \\
\text { The time and duration } \\
\text { of advertisement } \\
\text { As reminder of the } \\
\text { message } \\
\text { advertisement }\end{array}$ & $\begin{array}{l}\text { This scale used } 1-5 \\
\text { Likert scale of } \\
\text { agreement }\end{array}$ \\
\hline $\begin{array}{l}\text { Effective } \\
\text { Advertisement } \\
\text { (Environmental } \\
\text { Response) } \\
\mathrm{X}_{2}\end{array}$ & $\begin{array}{l}\text { The environmental } \\
\text { response happens when } \\
\text { the advertising can create } \\
\text { the experience of the } \\
\text { consumer through the } \\
\text { opinion and comment } \\
\text { about the product } \\
\text { (Abideen, 2012) }\end{array}$ & $\begin{array}{l}\text { - The good place } \\
\text { The availability of } \\
\text { information } \\
\text { The Hospitality of the } \\
\text { Brand Ambasaddor or } \\
\text { the employees }\end{array}$ & $\begin{array}{l}\text { This scale used } 1-5 \\
\text { Likert scale of } \\
\text { agreement }\end{array}$ \\
\hline $\begin{array}{l}\text { Brand Image } \\
\mathrm{X}_{3}\end{array}$ & $\begin{array}{l}\text { Brand is an image that } \\
\text { people can easily to } \\
\text { remember, recall, and } \\
\text { gives the positive } \\
\text { perception of the product } \\
\text { (Aaker, 1997 as cited in } \\
\text { Fianto, 2014). }\end{array}$ & $\begin{array}{l}\text { - The brand image of } \\
\text { Wardah as Halal } \\
\text { Cosmetic } \\
\text { The naturality of } \\
\text { Wardah products } \\
\text { The guarantee of } \\
\text { Wardah quality products }\end{array}$ & $\begin{array}{l}\text { This scale used } 1-5 \\
\text { Likert scale of } \\
\text { agreement }\end{array}$ \\
\hline $\begin{array}{l}\text { Packaging } \\
\mathrm{X}_{4}\end{array}$ & $\begin{array}{l}\text { Packaging is done to } \\
\text { guarantee the quality of } \\
\text { the product that the } \\
\text { consumer minor } \\
\text { experience, as appearence } \\
\text { of product performance in } \\
\text { order to communicate } \\
\text { with consumers and to } \\
\text { maintain the sustainability } \\
\text { of the product (Azzi et al } \\
\text { as cited in Hess et al, } \\
2014 \text { ) }\end{array}$ & $\begin{array}{l}\text { - The uniqueness of } \\
\text { Wardah packaging } \\
\text { - The convenience of } \\
\text { Wardah Packaging } \\
\text { - The good and safety of } \\
\text { Wardah packaging }\end{array}$ & $\begin{array}{l}\text { This scale used } 1-5 \\
\text { Likert scale of } \\
\text { agreement }\end{array}$ \\
\hline
\end{tabular}




\begin{tabular}{|c|c|c|c|}
\hline $\begin{array}{l}\text { Pricing } \\
\mathrm{X}_{3}\end{array}$ & $\begin{array}{l}\text { Price is a set of the } \\
\text { monetary value of the } \\
\text { product which are sold } \\
\text { and offered for sale to } \\
\text { consumers (Chatterjee. } \\
2008 \text { as cited in Dhurup, } \\
\text { Afini, \& Dumasi, 2014;) }\end{array}$ & $\begin{array}{l}\text { - The affordable price of } \\
\text { Wardah } \\
\text { - The guarantee price of } \\
\text { Wardah quality product } \\
\text { - The competitive price of } \\
\text { Wardah }\end{array}$ & $\begin{array}{l}\text { This scale used 1- } \\
\text { Likert scale } \\
\text { agreement }\end{array}$ \\
\hline $\begin{array}{l}\text { Consumer } \\
\text { buying } \\
\text { Attitude } \\
\mathrm{Y}_{1}\end{array}$ & $\begin{array}{l}\text { Consumer buying attitude } \\
\text { is a part of activities of } \\
\text { buying process that } \\
\text { involves belief, trust, } \\
\text { emotional feeling and } \\
\text { behavior intentions to } \\
\text { purchase the product or } \\
\text { brand repeatedly (Poranki } \\
\text { and Perwej, 2014). }\end{array}$ & $\begin{array}{l}\text { - The halal ingredients of } \\
\text { Wardah } \\
\text { The naturality of } \\
\text { Wardah } \\
\text { - The interest } \\
\text { affordable price } \\
\text { The interest in Wardah } \\
\text { advertisement } \\
\text { - The interest of Wardah } \\
\text { Packaging }\end{array}$ & $\begin{array}{l}\text { This scale used } \\
\text { Likert scale } \\
\text { agreement }\end{array}$ \\
\hline
\end{tabular}

\begin{tabular}{|c|c|c|c|}
\hline $\begin{array}{l}\text { Income } \\
Z_{1}\end{array}$ & $\begin{array}{l}\text { This demographic is } \\
\text { related to the purchasing } \\
\text { power of the area. The } \\
\text { income of each student } \\
\text { will contribute the } \\
\text { purchasing power in an } \\
\text { area. According to } \\
\text { Nguyen and Gizaw } \\
\text { (2014), income can } \\
\text { influence the attitude and } \\
\text { style of consumers }\end{array}$ & $\begin{array}{l}\text { - The amount of money that } \\
\text { female university students } \\
\text { got monthly }\end{array}$ & $\begin{array}{l}\text { This scaled used } \\
\text { multiple choice a-d } \\
\text { of each amount that } \\
\text { represents their } \\
\text { monthly income }\end{array}$ \\
\hline
\end{tabular}

The researcher gave 220 questionnaires for respondents who were using Wardah cosmetic. From 220 questionnaires, the researcher received 200 questionnaires in the field. The type of questionnaire was closed questionnaire. There were five parts of questions based on the effectiveness of advertising variables, brand image variables, packaging variables, pricing variables, income variables and buying attitude variables.

The scale of each question used Likert scale by five levels of agreement (Vagias, 2006) as follow (strongly disagre, disagree, neither disagree or agree, agree, and strongly agree).

\section{Data Analysis Method}

Before the data is being used for the calculation and analysis of this research, it is necessary to test the quality of the data first with the validity and reliability of data. The indicators and variable construct which qualified for further data quality test by using a two-stage regression analysis. The analysis tool once used to prove the hypothesis-hipotesi predetermined. The deduction is done through the testing procedure and the six criteria for testing the following hypothesis: normality test, multiple linear regression, Multicollinearity, Heteroscedasticity test, partial test (ttest) and R2 (coefficient of determination). All calculations and analyzes were conducted this study using the help of a data processing program SPSS ver. 2.0.

\section{Regression Analysis}

\section{Multiple linear regression analysis without moderating variable}

Multiple linear regression models can be used to see the effect of some independent variable on the dependent variable. The dependent variable is assumed random/stochastic, which means having a probabilistic distribution. The independent variable is assumed to have a fixed value (in 
repeated sampling). In this research, there were four independent variables used to test of each independent variables relationship with the dependent variables. The multiple linear regression equation used in this research was as follow:

$$
Y: b_{1} x_{1}+b_{2} x_{2}+b_{3} x_{3 a}+b_{4} x_{3 b}+b_{5} x_{3 c}+b_{5} x_{4 a}
$$

Description: $\mathrm{Y}$ is Consumer buying Attitude, $\mathrm{X}_{1}$ is Effective Advertising (Emotional Response), $\mathrm{X}_{2}$ is Effective Advertising (Environmental response, $\mathrm{X}_{3 \mathrm{a} \text { : }}$ is Brand Image, $\mathrm{X}_{3 \mathrm{~b}}$ is Packaging, $\mathrm{X}_{3 \mathrm{c}}$ is Price and $\mathrm{X}_{4 a}$ is Extrinsic Cues

\section{Moderated regression analysis}

This analysis is used to assume that there is an influence of moderating variable of the independent variable (pricing) on the dependent variable (consumer buying attitude). The multiple linear regression equation (with moderating variable) used in this research was follow:

$$
Y: b 1 x_{1}+b_{2} x_{2}+b_{3} x_{3 a}+b_{4} x_{3 b}+b_{5} x_{3 c}+b_{5} x_{4 a}+b_{6} x_{4 b}+b_{7} x_{4 a} * 4 b
$$

Description: $\mathrm{Y}$ is Consumer buying Attitude, $\mathrm{X}_{1}$ is Effective Advertising (Emotional Response), $\mathrm{X}_{2}$ is Effective Advertising (Environmental Response), $\mathrm{X}_{3 \mathrm{a}}$ is Brand Image, $\mathrm{X}_{3 \mathrm{~b}}$ is Packaging, $\mathrm{X}_{3 \mathrm{c}}$ is Pricing, $\mathrm{X}_{4 a}$ is Extrinsic Cues, $\mathrm{X}_{4 \mathrm{~b}}$ is Income, and $\mathrm{X}_{4 a}{ }^{*} \mathrm{X}_{4 \mathrm{~b}}$ is Income as moderating extrinsic cues.

\section{Result and Discussion}

In accordance with the problems and the formulation of models that had been raised as well as the interests of hypothesis testing the analytical technique used in this research included the Multiple Linear Regression Analysis. The data collection method was used the questionnaire distributed to the female university students in Yogyakarta. The amount of 120 questionnaires were distributed by google forms, and 100 questionnaires were directly distributed to consumers. However, after filtering the questionnaires, only 200 questionnaires were qualified to be processed.

The value of Cronbach's alpha for the variable of income was 1.0, effective advertisement (emotional response was 0.662 and environmental response was 0.618), extrinsic cues (brand image was 0.619 , packaging was 0.721 , and price was 0.669 ), and consumer buying attitude was 0.666 which mean, all variables were greater than the value of 0.6. Thus, the answers of respondents of the research variables are reliable. Therefore, the questionnaire of the variables was reliable and could be used for further research.

In the multiple linear regression model, income as the moderating variable used to determine the income variable moderating the independent variable which extrinsic cues (brand image, packaging, and price) toward consumer buying attitude of female university students on Wardah cosmetic in Yogyakarta. The results of multiple regression calculation by using SPSS were presented in Table 2 and 3 below.

From the table, there were positive and significant influence of emotional response toward consumer buying attitude (p-value $0.002<$ significant level 0.05). This means that if the emotional response is increasing, the consumer buying attitude will be increasing. The positive and significant influence of environmental response toward consumer buying attitude ( $\mathrm{p}$-value $0.009<$ significant level 0.05). This means that if the environmental response is increasing, the consumer buying attitude will be increasing. The positive and significant influence of brand image toward consumer buying attitude ( $\mathrm{p}$ value $0.021<$ significant level 0.05 ). This means that if the brand image is increasing, the consumer buying attitude will be increasing.

There were positive and significant influence of packaging toward consumer buying attitude ( $\mathrm{p}$-value $0.002<$ significant level 0.05). This means that if packaging is increasing, the consumer buying attitude will be increasing. 
Table 2. Multiple Linear Regression Analysis without Moderating Variable

\begin{tabular}{|c|c|c|c|c|c|c|}
\hline & & & Coefficient & & & \\
\hline & & Unsta & d Coefficients & $\begin{array}{l}\text { Stan } \\
\text { Coef }\end{array}$ & & \\
\hline Model & & B & Std. Error & Beta & $\mathbf{T}$ & Sig. \\
\hline 1 & (Constant) & 5.952 & 1.603 & & 3.713 & .000 \\
\hline & ER1 & 1.204 & .378 & .183 & 3.185 & .002 \\
\hline & ER2 & .168 & .104 & .086 & 2.610 & .009 \\
\hline & BI & .598 & .256 & .320 & 2.331 & .021 \\
\hline & Packaging & .341 & .195 & .212 & 3.749 & .002 \\
\hline & Price & .396 & .227 & .201 & 3.745 & .003 \\
\hline & Ec & .134 & .184 & .124 & 3.020 & .004 \\
\hline & Income & .521 & .325 & .133 & 3.604 & .010 \\
\hline
\end{tabular}

a. Dependent Variable: Consumer buying Attitude

Table 3. Multiple Regression Analysis with Income Variable (Moderate Variable)

\section{Coefficients $^{\mathrm{a}}$}

\begin{tabular}{llllll} 
& \multicolumn{2}{l}{$\begin{array}{l}\text { Unstandardized } \\
\text { Coefficients }\end{array}$} & \multicolumn{2}{l}{$\begin{array}{l}\text { Standardized } \\
\text { Coefficients }\end{array}$} \\
Model & B & Std. Error & Beta & T & Sig. \\
1 (Constant) & 2.554 & 1.289 & & 1.982 & .049 \\
ER1 & 1.055 & .290 & .161 & 3.634 & .000 \\
ER2 & .097 & .074 & .070 & 2.816 & .030 \\
BI & .186 & .078 & .141 & 2.393 & .018 \\
Packging & .236 & .084 & .119 & 2.793 & .006 \\
Price & .235 & .118 & .121 & 1.995 & .048 \\
Extrinsic & .371 & .149 & .192 & 2.487 & .014 \\
Income & .170 & .285 & .035 & 3.595 & .003 \\
moderating & 1.099 & .168 & .614 & 5.245 & .000
\end{tabular}

a. Dependent Variable:

Consumer buying Attitude

Source: primary data processed, 2015

A positive and significant influence of price toward consumer buying attitude (p-value $0.003<$ significant level 0.05). This means that if price is increasing, the consumer buying attitude will be increasing. There were positive and significant influence of extrinsic cues toward consumer buying 
attitude (p-value $0.004<$ significant level 0.05). This means that if extrinsic cues is increasing, the consumer buying attitude will be increasing.

Income had positive and significant influence on the extrinsic cues toward consumer buying attitude ( $\mathrm{p}$-value $0.000<$ significant level 0.05 ). This means if moderating variable is increasing, the extrinsic cues and consumer buying attitude will be increasing.

The next data testing was normality data test. Normality test is a test done to determine the normality and aims to test whether both the dependent variable and independent variables both have a normal distribution or not. Therefore, when the data has a normal distribution, Ttest can be done. While, if the normality assumption does not meet then the inference cannot be done with the T statistic. Normality test result with the Normal P-P Plot regression could be seen in the following figure:

\section{Normal P-P Plot of Regression Standardized}

\section{Residual}

\section{Dependent Variable: buying_attitude}

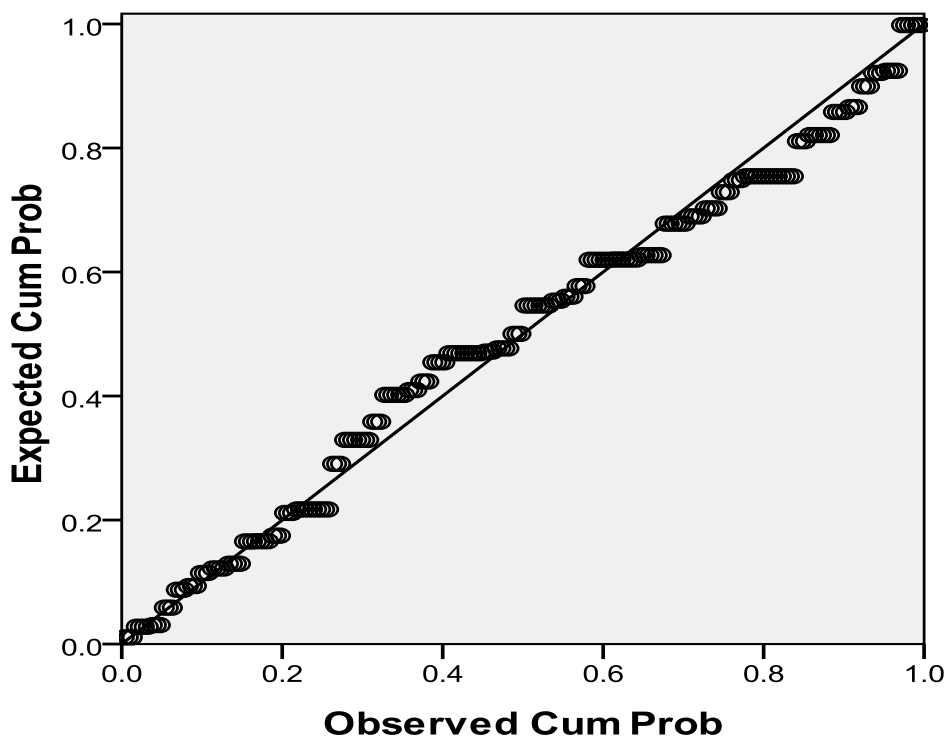

Figure 2. Normal P-P Plot of Regression

Based on the normal P-P Plot graph above, it could be seen that normal p-plot of regression standardized residual pattern of data spread around the diagonal graph was a straight line. This data is said as normally distributed. Thus, the above normality test showed that the normality assumption of the data is fulfilled.

The partial data test (t-test) showed that there were a positive influenced of emotional response, environmental response, extrinsic cues (brand image, packaging, and price), and income toward consumer buying attitude. The p-value of each variables were greather than $\alpha=0.05$.

Based on the table below, it showed that the value of VIF (Variance Inflation Factor) was $<10$. The VIF of emotional response $\left(\mathrm{X}_{1}\right)$ was 1.600 ; VIF of environmental response $\left(\mathrm{X}_{2}\right)$ was 1.386; VIF of the brand image $\left(\mathrm{X}_{3 \mathrm{a}}\right)$ was 9.113 ; VIF of packaging $\left(\mathrm{X}_{3 \mathrm{~b}}\right)$ was 7.063; VIF of price $\left(\mathrm{X}_{3 c}\right)$ was 6.377; VIF of extrinsic cues $\left(\mathrm{X}_{4 \mathrm{a}}\right)$ was 3.161 and the Tolerance value $>0.10$ or $<1$ to the tolerance value of emotional response $\left(\mathrm{X}_{1}\right)$ was 0.625 ; Tolerance of environmental value $\left(\mathrm{X}_{2}\right)$ was 0.721; Tolerance value of the brand image $\left(\mathrm{X}_{3 \mathrm{a}}\right)$ was 0.110 ; Tolerance value of packaging $\left(\mathrm{X}_{3 \mathrm{~b}}\right)$ was 0.142; Tolerance value of packaging $\left(\mathrm{X}_{3 c}\right)$ was 0.157 ; and Tolerance value of extrinsic cues $\left(\mathrm{X}_{4 a}\right)$ was 0.043 . Thus, based on the value of VIF (Variance Inflation Factor) and Tolerance, it 
could be concluded that the regression model did not contain multicollinearity. Therefore, the further testing can be continued because it has qualified classic assumption test that has not the case of multicollinearity.

Table 4. Partial Test (T-Test) with Moderating Variables

\begin{tabular}{|c|c|c|c|c|c|}
\hline \multicolumn{6}{|c|}{ Coefficients ${ }^{2}$} \\
\hline & \multicolumn{2}{|c|}{$\begin{array}{l}\text { Unstandardized } \\
\text { Coefficients }\end{array}$} & \multirow{2}{*}{$\begin{array}{c}\text { Standardized } \\
\text { Coefficients } \\
\text { Beta }\end{array}$} & \multirow[b]{2}{*}{$\mathbf{T}$} & \multirow[b]{2}{*}{ Sig. } \\
\hline Model & B & Std. Error & & & \\
\hline 1 (Constant) & 2.554 & 1.289 & & 1.982 & .049 \\
\hline ER1 & 1.055 & .290 & .161 & 3.634 & .000 \\
\hline ER2 & .097 & .074 & .070 & 2.816 & .030 \\
\hline BI & .186 & .078 & .141 & 2.393 & .018 \\
\hline Packaging & .236 & .084 & .119 & 2.793 & .006 \\
\hline Price & .235 & .118 & .121 & 1.995 & .048 \\
\hline Extrinsic & .371 & .149 & .192 & 2.487 & .014 \\
\hline Income & .170 & .285 & .035 & 3.595 & .003 \\
\hline Moderating & 1.099 & .168 & .614 & 5.245 & .000 \\
\hline
\end{tabular}

The multicolinearity test also conducted in this research.

Table 5. Multicolinearity Test

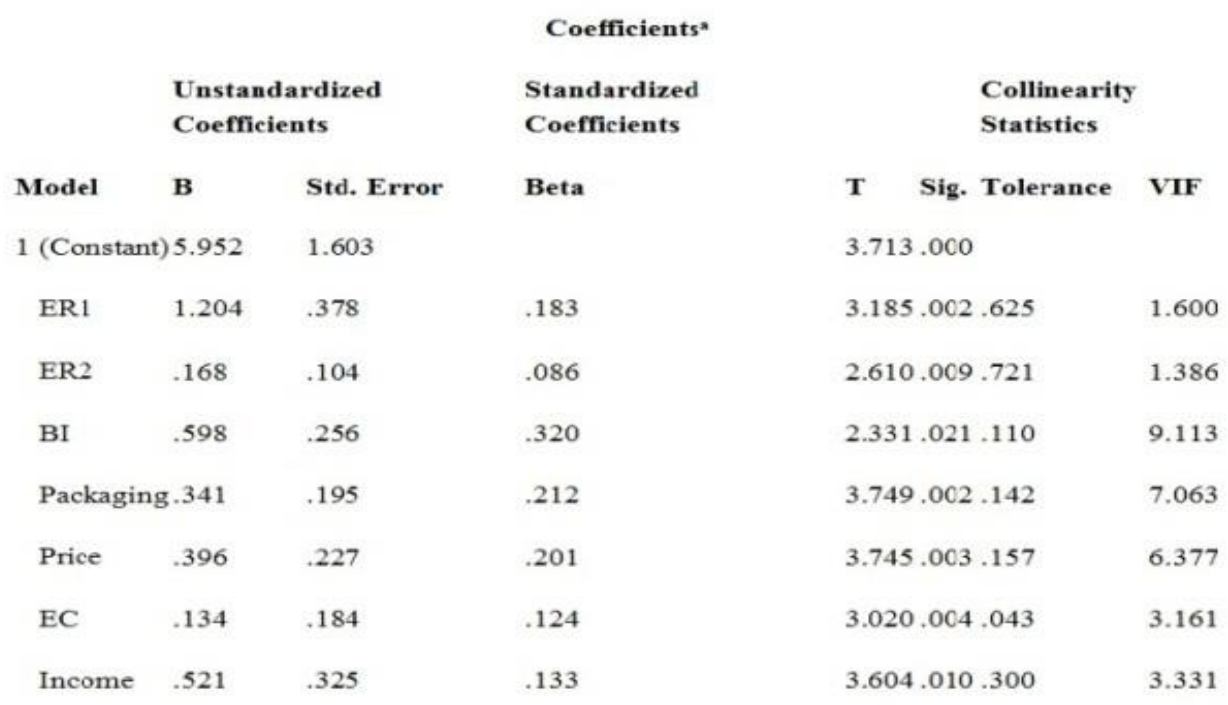

Heteroscedasticity arises when the variance of the probability distribution is not a constant nuisance for the entire observation of the research variables. This heteroscedasticity test method in this research was using a Scatterplot plot diagram.

The Scatterplot graph in figure 3 showed that scatterplot pattern of the existing data. The spreading pattern of data as dots on a scatterplot was above and below the graph and the distribution did not form a specific pattern. It is resulting the spreading pattern can be inferred that the heteroscedasticity did not happen in this research.

The correlation and coefficient determination of all variables also conducted in this research. The result showed $\mathrm{R}$ value of 0.776 indicated that the variable of emotional, environmental, brand image, packaging, price and extrinsic cues had a positive correlation of 0.776 toward the consumer buying attitude. The rated $\mathrm{R}$ square was 0.588 indicated that the amount of the role or contribution of emotional variables, environmental, brand image, 
packaging, price and extrinsic cues able to explain the variable of consumer buying attitude by $58.8 \%$ while the remaining $41.2 \%$ was explained by the main other variables used in this research.

Scatterplot

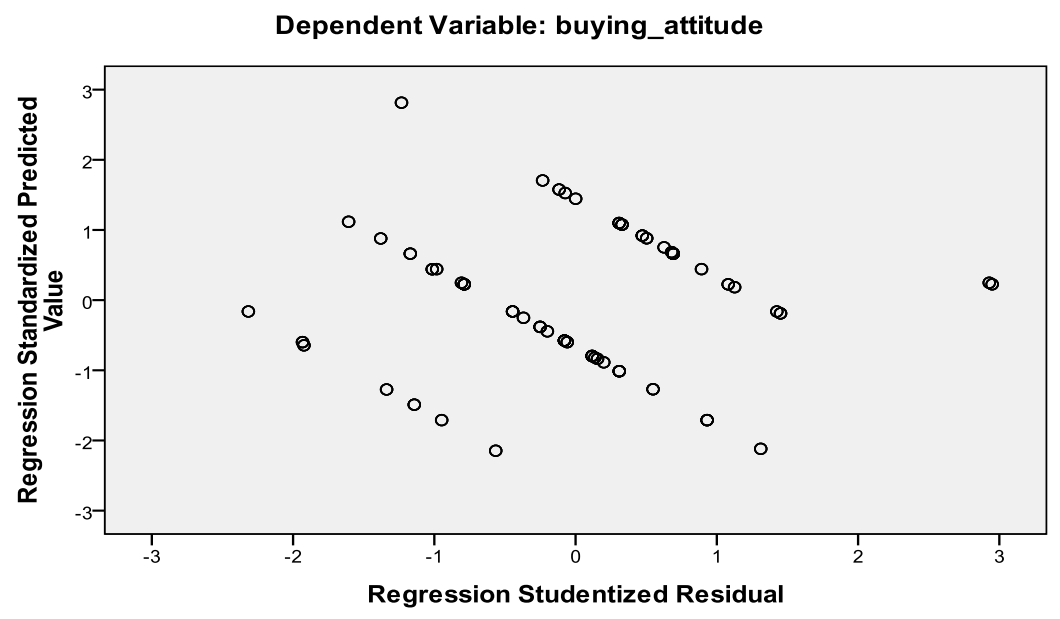

Figure 3. Scatterplot of buying attitude

It was significantly increasing when the correlation and coefficient determination showed the result with moderating variable. The $\mathrm{R}$ value of 0.870 indicated that the variable of extrinsic cues and income as moderating variables had correlation at 0.870 toward the consumer buying attitude. Adjusted R-square (R2) of 0.747 showed that the amount of the role or contribution of the extrinsic cues moderated by income variable was $74.7 \%$, while the remaining $25.3 \%$ was explained by other variables that used in this research.

The last result was partial coefficient of determination. It showed that The results of coefficients of the partial determination $\left(\mathrm{r}^{2}\right)$ in the first equation which were known as the emotional response toward the consumer buying attitude was $22.4 \%$, environmental attitude toward consumer buying attitude of $11.5 \%$, the brand image toward the consumer buying attitude was $16.6 \%$, packaging toward the consumer buying attitude was $12.5 \%$, the price toward the consumer buying attitude was $12.5 \%$, and the extrinsic cues toward the consumer buying attitude was $0.1 \%$. Thus, from these six variable coefficients partial determinations $\left(\mathrm{r}^{2}\right)$ were shown by the emotional response that had the largest amount of $22.4 \%$. Thus, the emotional response had a dominant influence on the consumer buying attitude.

\section{Conclusion}

Based on the discussion above, it seems that effective advertisement (emotional response and environmental response), and extrinsic cues (brand image, packaging and price) have a positive influence toward the consumer buying attitude as well as using income as the moderating variable of extrinsic cues toward the consumer buying attitude. The highest role of contributions each variables toward the consumer buying attitude was the emotional response.

Therefore, the researcher found a recommendation for marketer of Wardah company could use this research as consideration of the marketing decision making process. The emotional response showed that the advertisement of Wardah effectively persuaded the consumer to buy the product. It means that Wardah can maintain the concept of emotional response, the message in advertisement, to strengthen the consumer's perception and impulse them to buy the product.

For other researchers, this research, conducts causal study that shows the relationship between the effective advertisement and extrinsic cues that links to the consumer buying attitude. 
In order to complement and enhance the research, the researchers can focus on other factors that might influence the consumer buying attitude or the factors which can increase the emotional response of Wardah consumers toward consumer buying attitude to be observed.

According to the recommendations above, the next research should be widely sampled to achieve the higher significant result and have different location or expand the population or sample of the research. As emotional response has bigger role in this research, the next research could be observed about the factors that might inlfuence the emotional response toward consumer buying attitude or seeking other factors that may affect the consumer buying attitude which are not included in this research.

\section{Reference}

Abbasi, A. S. (2011). The Impact of Advertising on Brand Loyalty with the moderation of Consumer Behavior; Conceptual Frame Work. Interdiscplinary Journal of Contemporary Research in Business 3 (4), 501-513.

Abideen, Z., Farooq, W \& latif, A. (2011). How Urban Children Process Advertising Message: Special Reference to Television Advertising in Pakistan. African Journal of Business Management, 5(10), 3962-3974. DOI: 10.5897/AJBM11.014

Abideen, Z. \& Saleem, S. (2012). Effective advertising and its influence on consumer buying. European Journal of Business and Management 3(3), 55-65.

Acebro, L. B., \& Dopico, D. C. (2000). The importance of intrinsic and extrinsic cues to expected and experienced quality: an empirical application for beef. Food Quality and Preference 11 (2000), 229-238. Retrieved from: http:// citeseerx.ist.psu.edu/viewdoc/download?doi=10.1.1.499.5415\&rep=rep1\&type $=p$ df

Ahmed, R. R., Parmar, V., \& Amin, M. A. (2014). Impact of Product Packaging on Consumer's Buying Behavior. European Journal of Scientific Research 120 (2), 145-157. Retrieved from: https://pdfs.semanticscholar.org/60a5/de0f6f52fb938dd2a611e2ce4fe924570e01.pdf

Anwar, A. (2011). Impact of Brand Image, Trust, and Affect on Conumser Brand Extension Attitude the Mediating Role of Brand Loyalty. International Journal of Economics and Management Science 1(5), 73-79.

Arshad, H. M., Noor, D. M., Noor, N., Ahmad, W., \& Javed, S. (2014). Impact of Effective Advertising on Consumer Buying Behavior:A Study of Mobile Phone Purchasers in Pakistan. Journal of Basic and Applied Scientific Research 4(3), 224-231.Retrived from: https://pdfs.semanticscholar.org/0fec/8058813f1d8a5dbbcb0a2b05543f58024c20.pdf

Ayanwale, A. B. (2005). The Influence of Advertising on Consumer Brand. Journal of Social Science 10(1), 9-16. Retrieved from:

http://citeseerx.ist.psu.edu/viewdoc/download?doi=10.1.1.470.6021\&rep=rep1\&type=pdf

Bashar, A. (2013). A Study of Influence of Demographic Factors on Consumer Impulse Buying Behavior. Journal of Management Research, 13(3), 145-154.

Battaglia, M. P. (2011). Non-Probability Sampling. SAGE, pp. 523-526.

Brosekhan, A., Velayutham, \& Muthu. (2011). Consumer Buying Behaviour - Literature Review. IOSR Journal of Business and Management, 8-16. Retrieved from: https://pdfs.semanticscholar.org/2d34/87f2ecc3016af409838b2f4abe5c396f79af.pdf

Carvalho, C. A. (2013). Impact of Consumer Attitude in Predicting Purchasing Behaviour. 1-12. Retrieved from: 
http://www.iaso.com.br/pdf/Impact $\% 20$ of $\% 20$ Consumer $\% 20$ Attitude $\% 20$ in $\% 20$ Predic ting $\% 20$ Purchase $\% 20$ Behaviour.pdf

Ciputra Entrepreneur. (2015, June 28). womenpreneur. Retrieved October 11, 2015, fromciputraentrepreneurship.com:http://www.ciputraentrepreneurship.com/domesticwomenpreneur/bangkrut-setelah-kebakaran-kini-omzetnya-rp-200-miliar-sebulan

Dhurup, afini, \& Dumasi. (2014). The Impact of Packaging, price and brand awareness on brand loyalty: Evdence from the paint retailing industry. Acta Commercii 14(1), 194, 1-9. DOI: http://dx.doi. org/10.4102/ac.v14i1.194,

Fianto, A. Y. (2014). The Influence of Brand Image on Purchase Behaviour Through Brand Trust. Business Management and Strategy 5(2), 58-76.

Ghozali, I. (2005). Analisis Dengan Program SPSS. Semarang: Badan Penerbit Universitas Diponegoro.

Global Business Guide Indonesia. (2014). Macnufaturing. Retrieved october 09, 2015, from Global Business Guide Indonesia: http://www.gbgindonesia.com/en/manufacturing/article/2014/indonesia_s_cosmetics_ market.php

Habib, S. N. (2014). Analysis toward Brand Credibility and Brand Involvement of Brand Equity in Product Smartphone Samsung. Unpublished post undergraduated Universitas Islam Indonesia.

Hess, J. S. (2014). The Impact of Consumer Product Package Qualityon Consumption Satisfaction, Brand Perceptions, Consumer Investment and Behavior . Journal of Applied Packaging Research 6(1), 23.

Kebir, D.-e. (2011). Situational Factors Influencing Impulse Buying Behavior of Algarian Consumer. Romanian Journal of Marketing 6(2), p. 52-59.

Kotler. (2001). Marketing Management Millenium Edition. New Jersey: Pearson Custom Publishing.

Kumar, D. D. (2013). The Role of Advertising in Consumer Decision Making. IOSR Journal of Business and Management 14(4), 37-45. Retrieved from: https://pdfs.semanticscholar.org/b73f/90fd9441e0e2f0c654a9375da5730b08a8d8.pdf

Kumar, D., \& Kejriwal, R. (2014). Impact of Income on Media Selection by FMCG Consumers: A Study in Kolkata. The International Journal Of Business \& Management 2(5), 193-200.

Lin, C.-H., \& Tsai, C.-C. (2006). Comparisons and Advertising: The Route from Comparisons to Effective Advertising. Journal of Business and Psychology, 21(1), 23-44.

Malik, M. E. (2013). The Impact of Advertisement and Consumer Perception on Consumer Buying Behavior. International Review of Social Sciences and Humanities 6 (2), 55-64.

Nguyen, \& Gizaw, A. (2014). Factors that influence consumer purchasing decisions of Private Label Food Products. Bachelor thesis in business administration, 1-92.

Niazi, G. S. (2012). Effective Advertising and its Influence on Consumer Buying Behavior. Information Management and Business Review 4 (3), 114-119.

Pagis, N., \& Chowdhury, H. K. (2006). Consumer Evaluation of Beautification Poducts: Effects of Extrinsic Cues. Asian Academy of Management Journal (11), 89-104.

Poranki, K. R., \& Perwej, A. (2014). The buying Attitudes of Consumers of Cosmetic Products in Saudi Arabia. The International Journal Research Publication's 4 (8), 138-145. Retrieved from: https://pdfs.semanticscholar.org/7361/04f61b57ea96cbef516b0322d8df4359361b.pdf 
Rehman, F., Ilyas, M., Nawaz, T \& Hyder, S. (2014). How Facebook Advertising Affects Buying Behavior of Young Consumers:. Academic Research International 5 (4), 395-404.

Republika. (2012, September 03). Jumlah Mahasiswa Baru di Yogya Meningkat Siginifikan. Retrieved October 14, 2015, from Republika online: http://www.republika.co.id/berita/pendidikan/berita-pendidikan/12/09/03/m9s2mdjumlah-mahasiswa-baru-di-yogya-meningkat-siginifikan

Saha, S., Dey, M., \& Bhattacharyya, S. (2010). Factors Affecting Consumer Buying Behavior of Shoes in Kolkata: A Case Study. The IUP Journal of Management Research, 60 IX (4), 40-60.

Shukre, D. A., \& Mishra, N. (2012). Buying Behavior of Working Men and Women in Delhi/NCR. Anvesha, 5 (3), 23-30.

Supriadi, C. (2014, February 13). Wardah Jadi Merek Top Indonesia. Retrieve October 09, 2015, from Marketing.com: http://www.marketing.co.id/wardah-jadi-merek-top-indonesia/

Vagias, W. M. (2006). Likert-type scale response anchors. Clemson International Institute for Tourism \& Research Development, Department of Parks, Recreation and Tourism Management, 1-2.

Retrieved from: http://media.clemson.edu/cbshs/prtm/research/resources-for-researchpage-2/Vagias-Likert-Type-Scale-Response-Anchors.pdf

Waheed, A., Mahasan, S. S., \& Sandhu, M. A. (2014). Factor That Affects Consumer Buying Behavior: An Analysis of Some Selected Factors. Middle-East Journal of Scientific Research 19 (5), 636-641. DOI: $10.5829 /$ idosi.mejsr.2014.19.5.13623

Karbasivar, A \& Yarahmadi, H (2011). Evaluating Effective Factors on Consumer Impulse Buying Behavior. Asian Journal of Business Management Studies 2(4), 174-181. Retrieved from: https://idosi.org/ajbms/2(4)11/4.pdf 